\title{
Government Policy in Yogyakarta Special Region to Improve the Fulfillment of Educational Rights for Persons with Disabilities
}

\author{
Indra Ratna Dewi ${ }^{1}$ \\ Universitas Negeri Semarang \\ Semarang, Indonesia \\ indraratnaaaa@students.unnes.ac.id
}

\begin{abstract}
The alignment of Local Government Policy Yogyakarta Special Region of Yogyakarta Regulation No. 4 of 2012 on the Protection and Fulfillment Rights of Persons with Disabilities was discovered through the findings of this study. Yogyakarta Special Region Government Policy in an effort to strengthen the fulfillment of the right to education in accordance with the spirit of DIY Regulation No. 4 of 2012 on the Protection and Fulfillment of the Rights of Persons with Disabilities This is because these policies complement one other in their pursuit of inclusive education, as seen by the declaration of DIY as a field of inclusive education and the promise of financing education through BOSDA and crew scholarships. The policy also complies with Law No. 19 of 2011, which was enacted after the CRPD was ratified.
\end{abstract}

Keywords- Policy, Disabilities, Yogyakarta.

\section{INTRODUCTION}

Article 28C paragraph (1) and Article 31 paragraph (1) of the 1945 Constitution, for example, say that "every citizen has the right to education." This clause is reinforced by Law Number 20 of 2003 on the National Education System, which requires that education in Indonesia be conducted in a democratic, fair, and nondiscriminatory way while protecting human rights, religious values, cultural values, and national pluralism. Article 48 of Law Number 23 of 2002 Concerning Child Protection stipulates that "the government is required to provide basic education for all children for at least 9 (nine) years." "The state, government, family, and parents are obligated to provide the widest chance for children to get education," according to Article 49.[1]

These clauses stress that people with disabilities are Indonesian citizens with the same rights as everyone else, including the right to a good education, as stated in Article 3 paragraph (2) of the Human Rights Law No. 39 of 1999. In fact, the right to education in any path, form, or unit has been recognized in Law No. 4 of 1997 respecting Persons with Disabilities. The paradigm change in the terminology of persons with disabilities in Indonesia is inextricably linked to increased public awareness of their rights.[2]

The term "people with disabilities," which was once widely used, is now more commonly known as "people with disabilities." Since the ratification of the UN convention on the rights of persons with disabilities in November 2011 by Law Number 19 of 2011 about the ratification of the convention on the rights of persons with disabilities, the phrase "persons with disabilities" has been officially used in Indonesia. This paradigm shift is critical in rebuilding understanding, and it has a more positive meaning than the previous concept, which was based on charity (mercy) rather than the spirit of equal rights. [3]

Despite the fact that persons with disabilities continue to be treated as second-class citizens, their rights are frequently disregarded. However, it is hoped that, along with a paradigm shift in the terminology of persons with disabilities, the stereotype of people's opinions on the rights of persons with disabilities will change. The issue therefore becomes the application of legal foundations that should be able to ensure the rights of people with disabilities, particularly the right to receive decent education, but which have not been properly implemented. People with disabilities continue to encounter a variety of complex issues when it comes to accessing education, such as discriminatory behaviors and a lack of educational opportunities for children in general. These circumstances have an indirect impact on people with disabilities' self-acceptance, self-esteem, social standing, and personality.[4]

According to a survey undertaken by UNESCO, there are an estimated 113 million school-aged children globally, 90 percent of them reside in poor countries such as Indonesia and are illiterate. Persons with disabilities are a vulnerable population who frequently face such circumstances, with the majority of disabled families living in poverty. According to a survey, people with disabilities account for almost $20 \%$ of the world's poorest population. 98 percent of disabled children in underdeveloped nations do not attend school, 30 percent of the world's street children are disabled, and adults with impairments have a literacy rate of only $3 \%$.[5]

According to the findings of a survey performed by the Ministry of Social Affairs in 24 provinces, almost $60 \%$ of people with disabilities do not attend school or do not complete primary school, and nearly 89 percent do not have the skills required for employment. Based on the findings of the study, it can be stated that education, which should ideally be a social provision, still has issues 
reacting to dynamic global concerns, particularly for the lives of persons with disabilities.

\section{RESEARCH METHOD}

The method used in this research is experimental research. Whereas, the research design used in this research is quasi-experimental design with a nonequivalent control group design. This design consisted of two groups of subjects; the experimental and control group. Sugiyono (2014) states that in non-equivalent control group design, the experimental and control group are not chosen randomly. In this design, both experimental and control group are compared, because these groups are selected and placed without random choosing. The first stage of this method is measurement (pre-test) which was conducted to the experimental and control group and treatment was given within a certain period of time to the experimental group, then a remeasurement (post-test) was conducted to the experimental and control group to compare the conditions of the two groups before and after being given a treatment. Before and after treatment, students were given a learning motivation questionnaire as a pre-test and posttest. This was carried out to determine the improvement of students learning motivation after being treated by guidance and counseling group using the Motivational Interviewing technique. [7]

The subjects in this research were grade XI students of Senior Hight School Yogyakarta consisted of seven students as the experimental group and seven students as the control group. The sampling technique used in this research was purposive sampling. According to Sugiyono (2014) Purposive Sampling is a sampling technique with certain considerations. In this case, the consideration was students who had low learning motivation suggested from the recommendations of their guidance and counseling teacher. The instrument used in data collection was questionnaire. The type of questionnaire used in this study was closed questionnaire. Closed questionnaire provides alternative answers that have been determined by the researcher. The scale used in the questionnaire was Likert scale. The data analysis technique used in this research was the non-parametric analysis technique of the MannWhitney Test with SPSS version 20 application. [8]

\section{FINDINGS AND DISCUSSION}

The Indonesian government has responded to this challenge by ratifying Law No. 19 of 2011 on the Rights of Persons with Disabilities. The DIY Regional Regulation Number 4 of 2012 concerning the Protection and Fulfillment of the Rights of Persons with Disabilities was issued by the Special Region of Yogyakarta, which is the first province in Indonesia to issue a regional regulation that incorporates the contents of the CRPD into its articles.[6] The Regional Government and Regency/City Governments are required by the Regional Regulation to assist persons with disabilities in achieving equal educational opportunities in units, pathways, types, and degrees of education. The regulation went into effect in May 2014, two years after it was promulgated, and there are penalties for educational institutions that do not comply with its provisions.[7]

The Special Region of Yogyakarta, as a predicate of an educational area, has a vision and objective to provide outstanding educational services that respect the noble ideals of culture without discrimination. The declaration of DIY as an inclusion area on December 12, 2014 only adds to this. DIY strives to create an environment that is welcoming and attentive to individuals with disabilities, where their rights, including the right to education, are safeguarded and realized, particularly under the legislative cover of the DIY Regional Regulation Number 4 of 2012.[8]

Since the earthquake in Yogyakarta and Central Java in 2016, the number of people with impairments working in DIY has increased. According to data from the DIY Social Service, there will be 27,225 persons with disabilities in DIY in 2020, with 4511 people in Kulonprogo Regency, 6108 people in Bantul, 8037 people in Gunungkidul, 6642 people in Sleman, and 1967 people in Yogyakarta. Gunungkidul, the district with the most individuals with disabilities in DIY in 2021, is followed by Sleman, Kulonprogo, Bantul, and lastly Yogyakarta City.

While there is no statistics on the number of persons with disabilities who are still in school age, it is known that there are 9,096 children with special needs (ABK) of school age in DIY at the end of 2020. There are 4,782 kids who have attended and are now attending SLB, and 2,388 students who are enrolled in inclusive education programs. The remaining 1,926 ABK school-aged children have yet to be treated due to a variety of issues. This suggests that persons with disabilities continue to have a low degree of educational involvement. The authors are interested in learning more about the initiatives implemented by the government of the Special Region of Yogyakarta in order to promote the fulfillment of persons with disabilities' education rights under Regional Regulation Number 4 of 2012.[9]

The purpose of this Governor Regulation is to clarify the application of Article 6 of DIY Regional Regulation No. 4 of 2012 about the Protection and Fulfillment of the Rights of Persons with Disabilities. The DIY Education Office and Hellen Keller International, which is involved in disability issues, collaborated on the policy for implementing inclusive education. The Special Education System and the Inclusive Education System are in charge of providing education to people with disabilities. The inclusive education system is one in which all students with disabilities, as well as those who have the potential for intelligence and/or particular talents, are able to engage in education or learn in an educational environment alongside other students. The goal of an inclusive education system is to offer people with disabilities with the same educational opportunities as people in other areas.[10] 
The district/city government is in charge of putting the inclusive education system in place. The special education system, on the other hand, is directly supervised by the province government. As a result, APBD monies from districts/cities are used to subsidize the implementation of the inclusive education system. The provincial or DIY government, in this scenario, plays a role in facilitating and supporting the provision of special instructors or assistants in each inclusive education provider school. To put it another way, district/city governments are responsible for ensuring the provision of inclusive education resources at designated educational units, while the federal and provincial governments are responsible for aiding with the availability of inclusive education resources.[11]

As a result of the Governor's Regulation on Inclusive Education Implementation, every educational institution is required to admit children with special needs. Children with special needs who fall into the special needs category Visually impaired, deaf, speech impaired, mentally retarded, physically handicapped, mentally retarded, learning difficulties, slow learners, autism, epilepsy, have motor disorders, and become victims of drug, drug, and substance abuse are among the children who can participate in the inclusive education system. children living on the streets, child laborers, victims of violence, victims of natural disasters, and/or victims of social disasters, other addicts, have more than one disorder, have behavior that deviates from social and religious norms, have the potential for intelligence and/or special talents, children living on the streets, child laborers, victims of violence, victims of natural disasters, and/or victims of social disasters.[12]

Purwadi went on to say that schools that have been designated as inclusive education providers are "welcome." If there is an $\mathrm{ABK}$ who registers at the school, it must be accepted; nevertheless, if there is no $\mathrm{ABK}$ who registers, the school is not looking for $\mathrm{ABK}$ to be sent there (passive). This Governor Regulation is based on the Minister of National Education's Inclusive Education Regulation No. 70 of 2009. So, prior to the Regional Regulations and Governor Regulations, the National government had already adopted laws for the execution of inclusive education programs.[13]

The national program is then executed, and the regulations that govern it ensure its long-term viability. The Permendiknas explains the purpose of an inclusive education system in greater detail, namely to provide the widest opportunity for all students with physical, emotional, mental, and social disabilities, or who have the potential for special intelligence and/or talent, to obtain quality education in accordance with their needs and abilities, and to realize the implementation of education that respects diversity and is not discriminatory for all s.[14]

The inclusive education principle is tailored to the circumstances, requirements, and qualities of students. In each sub-district, the district/city administration assigns at least one elementary school and one junior high school. Because the quantity of teaching personnel, including special guidance instructors and inclusive education education staff (HR), is currently insufficient, not all schools are designated as inclusive education providers. The government of the Special Region of Yogyakarta regularly organizes training for educators in dealing with special needs children in order to facilitate the implementation of inclusive education. The number of schools using the inclusive education system continues to rise; according to the most recent data, there are around 300 inclusive schools ranging from elementary to high school. Throughout DIY, regent/mayor regulations govern further provisions surrounding the implementation of inclusive education in districts/cities.[15]

The purpose of this Governor Regulation is to put the requirements of Article 97 paragraph (4) of DIY Regional Regulation No. 4 of 2012 into effect. The Committee for the Protection and Fulfillment of the Rights of Persons with Disabilities, or the Committee for Persons with Disabilities, is an ad hoc non-structural institution that assists in the coordination and communication of implementation protection and fulfillment of the rights of Persons with Disabilities. Essentially, this committee was founded to ensure that the rights of people with disabilities, especially the right to education, are upheld. Anyone with a handicap who believes their rights have been violated can file a complaint with this council of disabled people. The DIY APBD is responsible for the committee's funding and administration. It is hoped that the rights of people with disabilities, especially the right to education, would be guaranteed and preserved by this committee.[16]

\section{CONCLUSION}

Based on the discussion results of this research, it can be concluded that the alignment of the Special Region of Yogyakarta's Policies with Regulation No. 4 of 2012 of the Special Region of Yogyakarta on the Protection and Fulfillment of the Rights of Persons with Disabilities The Special Region of Yogyakarta's policy aimed at increasing the realization of the right to education is in line with the spirit of Yogyakarta's Regional Regulation No. 4 of 2012 on the Protection and Fulfillment of the Rights of Persons with Disabilities. This is because these policies reinforce each other's efforts, and the declaration of DIY as an inclusive education zone, as well as the guarantee of education financing through BOSDA and $\mathrm{ABK}$ scholarships, add to the picture. This policy also complies with Law No. 19 of 2011, which was enacted as a result of the CRPD's ratification.

\section{REFERENCES}

[1] A. A. Herman and M. J. Hayat, "Management of High Secondary Education After Regional Government Law," $J$. Hum. Rights, Cult. Leg. Syst., vol. 1, no. 2, pp. 395-396, 2021.

[2] K. Wylie, G. Knudson, S. I. Khan, M. Bonierbale, S. Watanyusakul, and S. Baral, "Serving transgender people: clinical care considerations and service delivery models in transgender health," Lancet, vol. 388, no. 10042, pp. 401411, 2016. 
[3] S. R. Novikasari, D. Q. Ly, and K. Gershaneck, "Taxing Micro, Small and Medium Enterprises in Yogyakarta: Regulation and Compliance," Bestuur, vol. 9, no. 1, 2021.

[4] R. C. Sineath et al., "Determinants of and Barriers to Hormonal and Surgical Treatment Receipt among Transgender People," Transgender Heal., vol. 1, no. 1, pp. 129-136, 2016.

[5] D. M. Spencer, "Sanctuary cities and the power of the purse: An executive dole test," Iowa Law Rev., vol. 106, no. 3, pp. 1209-1251, 2021.

[6] I. Iswantoro, "Strategy and Management of Dispute Resolution, Land Conflicts at the Land Office of Sleman Regency," J. Hum. Rights, Cult. Leg. Syst., vol. 1, no. 1, pp. 1-17, 2021.

[7] S. D. Baranyanan, "Simplification of Law Regulations in Copyright Criminal Act Settlement," J. Hum. Rights, Cult. Leg. Syst., vol. 1, no. 2, pp. 80-91, 2021.

[8] A. K. Jaelani, I. G. A. K. R. Handayani, and L. Karjoko, "Development of halal tourism destinations in the Era of regional autonomy in West Nusa Tenggara Province," Int. J. Innov. Creat. Chang., vol. 12, no. 12, pp. 765-774, 2020.

[9] D. E. Wibowo, A. Sulistiyono, and L. Karjoko, "The application of the shifting burden of proof principles as an alternative consumer protection effort due to unfair property advertising," Int. J. Adv. Sci. Technol., vol. 28, no. 20, pp. 507-509, 2019.

[10] R. Res, "Implementation of Parate Executie Object of Liability Juridical Overview of Mortgage," J. Hum. Rights, Cult. Leg. Syst., vol. 1, no. 1, pp. 42-53, 2021.

[11] Syahlan, "Effective and Efficient Synchronization in Harmonization of Regulations Indonesia," J. Hum. Rights, Cult. Leg. Syst., vol. 1, no. 1, pp. 54-70, 2021.

[12] L. C. Lintang, Adriano Martufi, and J.W. Ouwerker, "The Alternative Concepts of Blasphemy Law in Indonesia: Legal Comparison with Ireland and Canada," Bestuur, vol. 8, no. 2, pp. 121-128, 2020.

[13] M. Pungky and H. Wijaya, "Legislation Impediments in Reorganising Government Bodies in Indonesia," Bestuur, vol. 9, no. 1, pp. 1-16, 2021.

[14] Saidah Fasihah Binti Che Yussoff and R. Nordin, "Freedom of Expression in Malaysia: Compatibility with the International Human Rights Standard Saidah," Bestuur, vol. 9, no. 1, pp. 44-59, 2021.

[15] U. K. Mishra and A. Negi, "Transgender and the Right to Employment in India: Analysing the Trajectories of Discrimination," Bestuur, vol. 9, no. 1, pp. 34-43, 2021.

[16] W. B. Putri et al., "Medicolegal Perspective on PhysicianInduced Demand Issue," Bestuur, vol. 9, no. 1, pp. 106124, 2021.

[17] Alizadegani F., Zaini M. F., dan Delavari G. Stress Free and High Self-Esteem: Approaches of Motivation towards Teachers and School Students. Malaysia: Journal Social and Behavioral Sciences Vol. 114, pp 711 - 714, 2014

[18] Erford, B. T. 2016. 40 Teknik yang Harus Diketahui Setiap Konselor. Terj-Soetjipto, dkk. Yogyakarta: Pustaka Belajar.

[19] Gredler, M. E. B. Belajar dan Membelajarkan. Jakarta: Rajawali, 1991.

[20] Hamalik, O. Psikologi Belajar dan Mengajar. Bandung: Sinar Baru., 1992.

[21] Istikasari, R. Self-Regulated Learning dengan Bimbingan Kelompok untuk Meningkatkan Motivasi
Belajar Siswa Kelas VIII SMP Negeri 2 Manyaran Wonogiri [Skripsi]. Surakarta: FKIP Universitas Sebelas Maret, 2015.

[22] Lundahl, B. \& Burke L. B. The Effectiveness and Aplicability of Motivational Interviewing: A Practice-Friendly Review of Four Meta-Analyses. Journal Clinical Psychology Vol. 65, pp 1233, 2009.

[23] Miller, W. R. \& Rollnick, S. Motivational Interviewing: Preparing People for Change, 2nd Edition. New York: Guilford Press, 2002.

[24] Pratiwi, D. M. Motivational Interviewing untuk Meningkatkan Motivasi Pada Mahasiswa S1. [Thesis]. Jakarta: Universitas Indonesia, 2014.

[25] Sugiyono. Metode Penelitian Kuantitatif Kualitatif dan $R$ \& D. Bandung: Alfabeta, 2014.

[26] Sun Q.-H. Song D., Xu T.-Z. Effect of motivational interviewing on self management in patients with type 2 diabetes. Journal of Nursing Sciences. Vol. 1, No. 3, pp. 291-297, 2014.

[27] Uno, H. B. Teori Motivasi dan Pengukurannya. Jakarta: Bumi Aksara, 2014.

[28] Wahab, R. Psikologi Belajar. Jakarta: PT. Raja Grafindo, 2015. 